\title{
Echokardiograficzna ocena prawych jam serca w praktyce klinicznej w świetle zaleceń ekspertów z 2015 roku
}

\author{
Echocardiographic assessment of the right heart \\ -2015 expert guidelines in clinical practice
}

\author{
Jan Błażejewski, Władysław Sinkiewicz \\ II Katedra Kardiologii Collegium Medicum w Bydgoszczy, Uniwersytet Mikołaja Kopernika w Toruniu
}

\section{Streszczenie}

Badania obrazowe serca mają kluczowe znaczenie w diagnostyce i monitorowaniu leczenia chorób serca. Echokardiografia, wśród dostępnych sposobów obrazowania, jest metodą z wyboru u pacjentów z podejrzeniem choroby serca, ze względu na dokładność, dostępność, bezpieczeństwo i koszty. Istotna wartość prognostyczna funkcji prawej komory dla przebiegu chorób układu krążenia sprawia, że jej prawidłowa ocena to konieczny element codziennej kardiologicznej praktyki klinicznej. Potwierdzeniem tej tezy oraz odpowiedzią na potrzeby klinicystów jest kolejna edycja zaleceń, w której rekomenduje się optymalne techniki i metodykę badania echokardiograficznego wraz z aktualizacją wartości referencyjnych poszczególnych parametrów. Najnowsze wytyczne dotyczące echokardiograficznej oceny jam serca u dorosłych opracowali eksperci American Society of Echocardiography oraz European Association of Cardiovascular Imaging i opublikowano je w 2015 roku. Podkreślono w nich konieczność oceny prawych jam serca podczas każdego badania echokardiograficznego, z uwzględnieniem informacji klinicznych dotyczących badanego i wykorzystaniem dostępnych okien akustycznych. Szczegółowy dobór metod zastosowanych u poszczególnych pacjentów jest indywidualizowany. Należy go dostosować do sytuacji i problemu klinicznego, warunków i możliwości badania, uwzględniając także umiejętności i doświadczenie personelu pracowni. W zaleceniach podkreśla się również konieczność odniesienia uzyskanych wyników do indywidualnych cech badanego, zwłaszcza w przypadku skrajnych wartości poszczególnych parametrów, co pozwala wyeliminować potencjalne błędy interpretacji uzyskanych wyników. Standardy echokardiograficznej oceny serca porządkują metodykę badania i zwiększają jego kliniczną wartość.

Słowa kluczowe: echokardiografia, prawa komora, prawy przedsionek, wytyczne

Folia Cardiologica 2017; 12, 2: 171-178

\section{Wstęp}

Badania obrazowe mają kluczowe znaczenie w diagnostyce i monitorowaniu leczenia chorób serca. Spośród dostępnych sposobów obrazowania metodą z wyboru u pacjentów z podejrzeniem choroby serca jest echokardiografia - ze względu na dokładność, dostępność (także mobilność), bezpieczeństwo i koszty. Dlatego, mimo że „złotym standardem” w ocenie objętości, masy i funkcji lewej (LV, left ventricle) i prawej komory (RV, right ventricle) serca pozostaje rezonans magnetyczny, w najnowszych zaleceniach rekomenduje się jego zastosowanie dopiero wtedy, gdy jakość badania echokardiograficznego jest niewystarczająca. Wynika to z ograniczeń zastosowania rezonansu magnetycznego, którymi mogą być: dostępność, ograniczone doświadczenie personelu pracowni, koszty, niepewność dotycząca bezpieczeństwa badania u pacjentów z metalowymi implantami, tachyarytmia u pacjenta,

Adres do korespondencji: dr n. med. Jan Błażejewski, Il Katedra Kardiologii, Szpital Uniwersytecki nr 2 im. dr. J. Biziela, ul. Ujejskiego 75, 85-168 Bydgoszcz, tel./faks 5236556 53, e-mail: janbi@o2.pl 
konieczność podania środka kontrastowego, klaustrofobia u badanego. Inne alternatywne badania obrazowe, takie jak tomografia komputerowa, pozytonowa tomografia emisyjna czy badania radioizotopowe, wykorzystuje się tylko w wybranych sytuacjach klinicznych. Zalecana i preferowana echokardiografia przezklatkowa, pozbawiona działań niepożądanych i przeciwwskazań, pozwala w większości przypadków uzyskać wystarczającą ocenę budowy i funkcji jam serca, także prawych [1].

Znaczenie RV, traktowanej początkowo jako bierny fragment układu krążenia, długo było niedoceniane. Jednakże wyniki badań wykazały istotną wartość prognostyczną funkcji RV w ocenie przebiegu chorób układu krążenia. Szczególnie obecność nadciśnienia płucnego, zarówno z cechami dysfunkcji RV, jak i bez nich, okazała się czynnikiem obciążającym rokowanie u pacjentów z niewydolnością serca [2, 3]. Nadal brakuje definicji nieprawidłowej funkcji RV oraz jednoznacznie określonych parametrów rozstrzygających o jej rozpoznaniu lub wykluczeniu. 0 ile w wytycznych European Society of Cardiology (ESC) wyraźnie pozycjonuje się znaczenie frakcji wyrzutowej lewej komory w rozpoznaniu niewydolności LV, o tyle w przypadku dysfunkcji RV brakuje jednoznacznie rekomendowanego parametru. Skomplikowany geometrycznie kształt RV (kształt litery V) - z częścią napływową i odpływową, bogate beleczkowanie oraz złożony mechanizm skurczu utrudniają ocenę jej czynności. Wystąpienie przeciążenia objętościowego lub ciśnieniowego (bądź współistnienie obu) stanowi mechanizm patofizjologiczny rozwoju dysfunkcji RV. Najczęstszą przyczyną przewlekłej prawokomorowej niewydolności serca jest niewydolność LV z podwyższeniem ciśnienia jej napełniania. Wzrost ciśnienia w łożysku żylnym krążenia płucnego może prowadzić do rozwoju wtórnego nadciśnienia płucnego - zależnego od choroby lewego serca. Także inne postaci nadciśnienia płucnego - spowodowane chorobami płuc, zakrzepowo-zatorowe czy rzadko występujące tętnicze nadciśnienie płucne - zwiększają obciążenie RV i prowadzą do jej niewydolności. Inne sytuacje kliniczne, w których może wystąpić przewlekła niewydolność RV, to ostry zespół wieńcowy z niedokrwieniem RV, arytmogenna kardiomiopatia prawokomorowa i inne rzadsze kardiomiopatie, wrodzone lub nabyte wady serca [4].

Najistotniejsze elementy badania prawych jam serca to ocena ich budowy, pomiary wielkości komory i przedsionka oraz naczyń, wskaźniki funkcji skurczowej RV oraz parametry hemodynamiczne związane z jej pracą. Aktualne dane nie są wystarczające, by dokonać klasyfikacji dysfunkcji RV na łagodną, umiarkowaną i ciężką, jednak prawidłowo przeprowadzone badanie, a zwłaszcza interpretacja poszczególnych parametrów echokardiograficznych w odniesieniu do sytuacji klinicznej pacjenta, ułatwia podejmowanie optymalnych decyzji diagnostycznych i terapeutycznych. W wytycznych w sposób kompleksowy opisuje się wszelkie dostępne i wiarygodnie, udokumentowane metody oceny prawych jam serca, ustala ich wartość i rekomendacje w określonych stanach chorobowych. Stanowią fundament, na którym opierają się pracownie echokardiograficzne w codziennej praktyce klinicznej, decydują o jakości i standaryzacji badań i ich porównywalności.

W 2010 roku opublikowano wytyczne American Society of Echocardiography, (ASE), zaaprobowane przez European Association of Echocardiography (EAE), dotyczące echokardiograficznej oceny prawych jam serca u dorosłych, w których w szczegółowy sposób uporządkowano i opisano metodykę pomiarów, wartości referencyjne poszczególnych parametrów oraz interpretację uzyskanych wyników [5]. W 2015 roku ukazały się kolejne, najnowsze zalecenia dotyczące echokardiograficznej oceny jam serca u dorosłych opracowane przez ekspertów ASE i European Association of Cardiovascular Imaging (EACVI) [6]. W wytycznych sporo uwagi poświęca się ocenie prawych jam serca, uwzględnia nowe techniki badania oraz uzyskane w ostatnich latach wyniki badań naukowych. Wyniki te pozwoliły na aktualizację oceny poszczególnych metod badania echokardiograficznego oraz modyfikacje zakresów wartości referencyjnych i granic nieprawidłowości.

W nowych wytycznych podkreśla się konieczność oceny prawych jam serca podczas każdego badania echokardiograficznego z uwzględnieniem informacji klinicznych dotyczących badanego i wykorzystaniem dostępnych okien akustycznych. Projekcją przeznaczoną i rekomendowaną do oceny wielkości RV jest projekcja koniuszkowa czterojamowa skierowana na prawą komorę (4C-RV, RV-focused apical four-chamber view), która umożliwia pomiar jej maksymalnych poprzecznych wymiarów. Pomiary wykonane w typowej projekcji koniuszkowej czterojamowej (4C, apical four-chamber view) powodują, że uzyskane wartości są zmienne i w różnym stopniu zaniżone. Poza tym w badaniu wykorzystuje się wszystkie klasyczne projekcje echokardiograficzne i ewentualnie ich modyfikacje oraz projekcje dodatkowe (nietypowe), zależne od indywidualnych warunków danego badania i dostępnych okien akustycznych.

\section{Ocena wielkości prawych jam serca}

W warunkach prawidłowych koniuszek serca jest tworzony przez LV, która jest większa od RV. Wymiar RV nie powinien przekraczać 2/3 wymiaru LV. Jeżeli RV (w projekcji 4C) jest większa od LV, to prawdopodobnie świadczy to o jej znacznym powiększeniu, szczególnie gdy współtworzy koniuszek serca, jednakże tej tezy w wytycznych nie sprecyzowano ilościowo. Zgodnie z poprzednimi wytycznymi powiększenie RV można było rozpoznać nawet wtedy, gdy jej wymiar nie przekraczał normy, ale był wyraźnie większy od wymiaru LV [5]. Istotne jest, by pomiary wykonać w zalecanej projekcji 4C-RV. Głowica powinna być umieszczona dokładnie nad koniuszkiem serca i rotowana aż do momentu uzyskania maksymalnej wielkości RV przy zachowaniu płaszczyzny 
przekroju przechodzącej przez środek LV (z uwidocznieniem największej średnicy LV) oraz koniuszek LV. Jednocześnie należy pamiętać, by droga odpływu LV była niewidoczna, a więc aby uniknąć projekcji koniuszkowej pięciojamowej.

W ocenie wielkości prawych jam serca eksperci uwzględniają pomiary liniowe, pomiary pola powierzchni i objętości. Podstawowe są dwa liniowe pomiary szerokości RV, służące do oceny drogi napływu (inflow), wykonane w okresie końcoworozkurczowym - wymiar podstawny (nieco poniżej zastawki trójdzielnej, w obszarze segmentu podstawnego [RVD1, basal RV linear dimension]), który nie powinien przekraczać 4,1 cm oraz wymiar środkowy (na poziomie mięśni brodawkowatych LV, w zakresie segmentu środkowego RV [RVD2, mid-cavity RV linear dimension]), który nie powinien przekraczać $3,5 \mathrm{~cm}$. Wymiar podłużny prawej komory (RVD3, RV longitudinal dimension) według wytycznych nie powinien przekraczać $8,3 \mathrm{~cm}$, ale ze względu na jego dużą zmienność nie jest rekomendowany do rutynowej oceny wielkości RV. W zaleceniach wspomina się również o pomiarach drogi odpływu RV (outflow), rzadziej wykonywanych i bardziej istotnych we wrodzonych wadach serca, które wykonuje się w projekcjach przymostkowych. Pomiary te zazwyczaj są obarczone wyższym ryzykiem błędu zależnym od płaszczyzny obrazowania. Wynik każdego badania echokardiograficznego powinien zawierać przynajmniej jeden, precyzyjnie określony, wymiar RV.

Istotna jest ocena grubości wolnej ściany RV dokonana w końcowej fazie rozkurczu serca, optymalnie w projekcji podmostkowej. Przerost mięśnia RV, będący efektem jej przeciążenia, może występować u pacjentów z niewydolnością serca, zwłaszcza w przypadku współistnienia nadciśnienia płucnego. Wartość graniczna według wytycznych wynosi 0,5 cm, a jej przekroczenie należy odnotować w opisie badania echokardiograficznego.

Echokardiografia trójwymiarowa (3D, three-dimensional echocardiography) umożliwia pomiary objętościowe RV, takie jak objętość końcoworozkurczowa i końcowoskurczowa $\mathrm{RV}$, co pozwala obliczyć frakcję wyrzutową prawej komory. Zalecenia dotyczące obrazowania trójwymiarowego RV opublikowały EAE i ASE [7]. Szczególną uwagę zwraca się na manualny wybór odpowiednich faz cyklu serca, precyzyjne określenie granic wsierdzia z włączeniem beleczkowania i wiązki pośredniej do objętości RV oraz uwzględnienie przemieszczania pierścienia trójdzielnego. Metoda ta zaniża objętości RV w porównaniu z wartościami uzyskiwanymi podczas rezonansu magnetycznego, ale pozwala zachować zależności między tymi objętościami i frakcją wyrzutową prawej komory, płcią i wiekiem badanych [8]. Eksperci podkreślają znaczenie i zachęcają, aby opisywane parametry wolumetryczne odnosić (indeksować) do powierzchni ciała (BSA, body surface area) co, jak wskazują metaanalizy, zwiększa ich wartość.

Według wytycznych wielkość RV rutynowo należy oceniać przy użyciu parametrów liniowych w echokardiografii dwuwymiarowej (2D, two-dimensional echocardiography). Ocenę objętościową (3D) zaleca się tylko w wybranych przypadkach klinicznych - w pracowniach, których personel posiada odpowiednie doświadczenie. Ustalenie zakresu prawidłowych wartości objętości RV wymaga oceny większych grup pacjentów. Dotychczas opublikowane dane, według ekspertów, pozwalają przyjąć, że objętość końcoworozkurczowa RV wynosząca $87 \mathrm{ml} / \mathrm{m}^{2}$ u mężczyzn i $74 \mathrm{ml} / \mathrm{m}^{2}$ u kobiet oraz końcowoskurczowa wynosząca $44 \mathrm{ml} / \mathrm{m}^{2}$ u mężczyzn i $36 \mathrm{ml} / \mathrm{m}^{2}$ u kobiet stanowią górne granice normy. Wartości referencyjne podstawowych parametrów służących do oceny wielkości RV zawarto w tabeli 1.

Ocena wielkości prawego przedsionka (RA, right atrium) jest wskazana u każdego pacjenta z dysfunkcją RV lub LV [9]. Zalecaną projekcją do tej oceny jest projekcja koniuszkowa czterojamowa (4C), w której określa się jego wymiary liniowe, powierzchnię i objętość. Najczęściej jest oceniany wymiar mniejszy RA - od środka przegrody międzyprzedsionkowej do bocznej ściany RA, prostopadle do osi długiej serca. Rzadziej podaje się wymiar większy RA, tj. odległość od środka płaszczyzny pierścienia trójdzielnego do sklepienia RA mierzoną równolegle do przegrody międzyprzedsionkowej. W poprzednich wytycznych ASE nie dysponowano odpowiednimi danymi kohortowymi, pozwalającymi ustalić wartości prawidłowe zależne od płci, natomiast w aktualnych są one określone (tab. 2) [10]. Dokładniejszą metodą według ekspertów pozostaje pomiar powierzchni RA (projekcja 4C) - jego pole nie powinno przekraczać $18 \mathrm{~cm}^{2}$. Nowością w omawianych wytycznych jest sformułowanie, że referencyjna metoda oceny wielkości RA to jego objętość indeksowana BSA, oceniana metodą sumowania dysków przy użyciu echokardiografii 2D [11].

\section{Ocena funkcji skurczowej prawej komory}

W zaleceniach rekomenduje się wskaźniki, które odzwierciedlają globalną funkcję skurczową RV. Akceptuje się również niektóre wskaźniki regionalnej oceny funkcji mięśnia RV dobrze korelujące z jej funkcją globalną, co pozwala na ich stosowanie, przy zachowanej świadomości pewnych ograniczeń.

Wskaźnik sprawności prawej komory (RIMP) Wskaźnik sprawności prawej komory (RIMP, right ventricular index of myocardial performance), znany także jako wskaźnik Tei, wyraża odsetkową wartość, jaką stanowi suma czasu izowolumetrycznego skurczu i rozkurczu RV w stosunku do czasu wyrzutu krwi z RV. Wzrost tej wartości świadczy o globalnym upośledzeniu zarówno funkcji skurczowej, jak i rozkurczowej komory. Pomiar RIMP można wykonać dwiema metodami. Pierwsza metoda, przy użyciu doplera tkankowego (TDE, tissue Doppler echocardiography) rejestrującego ruch pierścienia trójdzielnego, pozwala na wykonanie pomiarów w jednej projekcji i jednym cyklu 
Tabela 1. Wielkość prawej komory (RV, right ventricle) - wartości referencyjne (na podstawie [6])

\begin{tabular}{|c|c|c|}
\hline Parametr & Wartość średnia \pm SD & Zakres normy \\
\hline Wymiar podstawny RV [mm] & $33 \pm 4$ & $25-41$ \\
\hline Wymiar środkowy RV [mm] & $27 \pm 4$ & $19-35$ \\
\hline Grubość ściany RV [mm] & $3 \pm 1$ & $1-5$ \\
\hline \multicolumn{3}{|l|}{$\mathrm{RV}$ EDA $\left[\mathrm{cm}^{2}\right]:$} \\
\hline • mężczyźni & $17 \pm 3,5$ & $10-24$ \\
\hline - kobiety & $14 \pm 3$ & $18-20$ \\
\hline \multicolumn{3}{|l|}{ RV ESA $\left[\mathrm{cm}^{2}\right]$ : } \\
\hline • mężczyźni & $9 \pm 3$ & $3-15$ \\
\hline - kobiety & $7 \pm 2$ & $3-11$ \\
\hline \multicolumn{3}{|c|}{ RV EDA indeksowana BSA $\left[\mathrm{cm}^{2} / \mathrm{m}^{2}\right]$ : } \\
\hline • mężczyźni & $8,8 \pm 1,9$ & $5-12,6$ \\
\hline - kobiety & $8,0 \pm 1,75$ & $4,5-11,5$ \\
\hline \multicolumn{3}{|c|}{ RV ESA indeksowana BSA $\left[\mathrm{cm}^{2} / \mathrm{m}^{2}\right]$ : } \\
\hline • mężczyźni & $4,7 \pm 1,35$ & $2,0-7,4$ \\
\hline - kobiety & $4,0 \pm 1,2$ & $1,6-6,4$ \\
\hline \multicolumn{3}{|c|}{ RV EDV indeksowana BSA $\left[\mathrm{ml} / \mathrm{m}^{2}\right]$ : } \\
\hline • mężczyźni & $61 \pm 13$ & $35-87$ \\
\hline - kobiety & $53 \pm 10,5$ & $32-74$ \\
\hline \multicolumn{3}{|c|}{ RV ESV indeksowana BSA $\left[\mathrm{ml} / \mathrm{m}^{2}\right]$ : } \\
\hline • mężczyźni & $27 \pm 8,5$ & $10-44$ \\
\hline - kobiety & $22 \pm 7$ & $8-36$ \\
\hline
\end{tabular}

SD (standard deviation) - odchylenie standardowe; EDA (end-diastolic area) - powierzchnia końcoworozkurczowa; ESA (end-systolic area) - powierzchnia końcowoskurczowa; BSA (body surface area) - powierzchnia ciała; EDV (end-diastolic volume) - objętość końcoworozkurczowa; ESV (end-systolic volume) - objętość końcowoskurczowa

Tabela 2. Wielkość prawego przedsionka (RA, right atrium) - wartości referencyjne (na podstawie [6])

$\begin{array}{lc}\text { Parametr } & \begin{array}{c}\text { Wartość } \\ \text { średnia } \pm \text { SD }\end{array} \\ \begin{array}{l}\text { Indeksowany BSA mniejszy wymiar RA }\left[\mathrm{cm} / \mathrm{m}^{2}\right] \text { : } \\ \text { • mężczyźni }\end{array} & 1,9 \pm 0,3 \\ \text { • kobiety } & 1,9 \pm 0,3 \\ \text { Indeksowany BSA większy wymiar RA [cm/m²]: } & \\ \text { • mężczyźni } & 2,4 \pm 0,3 \\ \text { • kobiety } & 2,5 \pm 0,3 \\ \text { Indeksowana BSA objętość RA }\left[\mathrm{ml} / \mathrm{m}^{2}\right] \text { : } & \\ \text { • mężczyźni } & 25 \pm 7 \\ \text { • kobiety } & 21 \pm 6\end{array}$

serca, dlatego wydaje się prostsza i obarczona niższym ryzykiem błędu. Według drugiej metody, wykorzystując spektrum doplera pulsacyjnego (PW, pulsed wave Doppler), wykonuje się pomiary w dwóch różnych projekcjach, a więc dwóch różnych cyklach pracy serca, umożliwiających ocenę napływu przez zastawkę trójdzielną i wyrzutu przez zastawkę płucną. Warunkiem prawidłowego pomiaru jest uzyskanie w obu projekcjach zapisu ewolucji serca o zbliżonym czasie RR. Wartość RIMP, według aktualnych zaleceń, nie powinna przekraczać 0,54 w przypadku użyciu TDE oraz 0,43 w przypadku wykorzystaniu PW. Wskaźnik jest zawodny u osób z migotaniem przedsionków oraz przy występowaniu wysokiego ciśnienia w RA.

Wskaźnik zmiany pola prawej komory (FAC) Kolejnym zalecanym wskaźnikiem oceny globalnej funkcji skurczowej RV jest wskaźnik zmiany pola prawej komory (FAC, fractional area change). Wskaźnik ten jest ilorazem rozkurczowo-skurczowej różnicy pola powierzchni RV i jej powierzchni rozkurczowej, wyrażonym w procentach. Jego oznaczenie jest dosyć czasochłonne i wymaga dobrej jakości obrazowania wsierdzia RV łącznie z jej koniuszkiem. Istotnym wymogiem metodycznym jest włączenie do powierzchni RV beleczkowania, płatków trójdzielnych i strun 
ścięgnistych. Wartości poniżej 35\% świadczą o upośledzeniu funkcji skurczowej RV i dobrze korelują z wartościami frakcji wyrzutowej prawej komory, uzyskanymi metodą rezonansu magnetycznego [12]. Wykazano związek wartości FAC z występowaniem niewydolności serca, ryzyka nagłego zgonu, udaru mózgu oraz śmiertelnością w przebiegu zatorowości płucnej i zawału serca [5].

\section{Frakcja wyrzutowa prawej komory}

Nowością w omawianych wytycznych jest ocena przydatności frakcji wyrzutowej prawej komory oznaczanej przy użyciu echokardiografii trójwymiarowej (RV 3D EF, right ventricle three-dimensional ejection fraction). Parametr ten jest wskaźnikiem globalnej funkcji RV odzwierciedlającym jej kurczliwość oraz obciążenie. Akceptacja opisywanych wyżej pomiarów wolumetrycznych RV uzasadnia takie stanowisko. Zaleca się wykorzystywanie funkcji automatycznej detekcji wsierdzia. Ograniczeniem tej metody jest dostępność oraz zależność od jakości obrazowania, miarowego rytmu serca i doświadczenia personelu pracowni. Jej wartość zwiększa rosnąca liczba badań porównawczych z wynikami uzyskiwanymi z zastosowaniem referencyjnego rezonansu magnetycznego [13, 14]. Uznaje się, że wartość RV 3D EF poniżej $45 \%$ wskazuje na dysfunkcję skurczową RV.

\section{Maksymalna skurczowa prędkość S'}

Pomiar maksymalnej skurczowej prędkości S' ruchu pierścienia trójdzielnego lub podstawnego segmentu wolnej ściany RV przy użyciu TDE jest metodą, w której wykorzystuje się parametr regionalny do oceny globalnej funkcji RV. Prawidłowy pomiar wymaga minimalizacji kąta odchylenia wiązki doplerowskiej od kierunku skurczu RV. Ograniczeniem jest obecność odcinkowych zaburzeń kurczliwości. Wartość szczytowej prędkości S' poniżej $9,5 \mathrm{~cm} / \mathrm{s}$ wskazuje na nieprawidłową funkcję RV, ale brakuje wystarczających danych dotyczących osób w podeszłym wieku [15]. W wytycznych zaleca się korzystanie z tego prostego i powtarzalnego parametru, zwłaszcza w grupie młodych dorosłych [5].

\section{Amplituda ruchu skurczowego pierścienia zastawki trójdzielnej (TAPSE)}

Najpowszechniej wykorzystywanym parametrem do oceny funkcji RV pozostaje amplituda ruchu skurczowego pierścienia zastawki trójdzielnej (TAPSE, tricuspidal annular plane systolic excursion). W zaleceniach podkreśla się, że jest to wskaźnik zależny od funkcji włókien podłużnych mięśnia RV, ale ponieważ objętość wyrzutowa RV w głównym stopniu zależy od ich funkcji, to wskaźnik ten dobrze odzwierciedla globalną czynność skurczową RV [16-18]. Pomiar nie jest czasochłonny i w mniejszym stopniu (niż powyżej opisywane wskaźniki) zależy od jakości obrazu. Według ostatnich zaleceń wartość TAPSE poniżej $17 \mathrm{~mm}$ wskazuje na upośledzenie funkcji skurczowej RV.
Tabela 3. Prawidłowe wartości parametrów funkcji prawej komory (RV, right ventricle) (na podstawie [6])

\begin{tabular}{lcc}
\hline Parametr & $\begin{array}{c}\text { Wartość średnia } \\
\pm \text { SD }\end{array}$ & $\begin{array}{c}\text { Granica nie- } \\
\text { prawidłowości }\end{array}$ \\
\hline TAPSE [mm] & $24 \pm 3,5$ & $<17$ \\
Prędkość S' (TDE) [cm/s] & $14,1 \pm 2,3$ & $<9,5$ \\
RV 3D EF (\%) & $58 \pm 6,5$ & $<45$ \\
RV FAC (\%) & $49 \pm 7$ & $<35$ \\
RIMP (TDE) & $0,38 \pm 0,08$ & $>54$ \\
RIMP (PW) & $0,26 \pm 0,085$ & $>43$
\end{tabular}

SD (standard deviation) - odchylenie standardowe; TAPSE (tricuspidal annular plane systolic excursion) - amplituda ruchu skurczowego pierścienia zastawki trójdzielnej; TDE (tissue Doppler echocardiography) - dopler tkankowy; EF (ejection fraction) - frakcja wyrzutowa; FAC (fractional area change) - wskaźnik zmiany pola prawej komory; RIMP (right ventricular index of myocardial performance) - wskaźnik sprawności prawej komory; PW (pulsed wave Doppler) - dopler pulsacyjny

\section{Odkształcenie i tempo odkształcenia (strain, strain rate)}

Ostatnim wskaźnikiem oceny funkcji RV, któremu w aktualnych zaleceniach poświęca się uwagę, jest pomiar odkształcenia i tempa odkształcenia (strain, strain rate). Dotychczasowa wiedza oparta na stosunkowo niewielkim materiale (wyniki zależne od oprogramowania pochodzącego od tylko dwóch producentów) według ekspertów jest obiecująca, ale obecnie zbyt skromna, by jednoznacznie ocenić jej przydatność kliniczną i sformułować zalecenia.

\section{Wskaźnik narastania ciśnienia \\ w prawej komorze (RV dP/dt)}

W nowych zaleceniach nie wspomina się o wskaźniku narastania ciśnienia w prawej komorze (RV dP/dt). W poprzednich wytycznych zwracano uwagę na brak ściśle określonych norm dla tego parametru oraz jego zależność od obciążenia komory oraz ciężkości fali zwrotnej trójdzielnej i nie zalecano jego rutynowego stosowania [5]. Należy uznać, że nie pojawiły się nowe badania, które zmieniłyby pogląd ekspertów na jego wartość. Zestawienie rekomendowanych parametrów do oceny funkcji RV przedstawiono w tabeli 3.

\section{Hemodynamiczne pomiary echokardiograficzne prawego serca}

Referencyjną metodą oceny parametrów hemodynamicznych w obrębie prawych jam serca i krążenia płucnego jest cewnikowanie serca. Szereg ograniczeń tej metody wynikających z jej inwazyjności, ograniczonej dostępności i kosztów sprawia, że echokardiografia jest powszechnie wykorzystywana do tych celów, zwłaszcza u pacjentów z niewydolnością serca i nadciśnieniem płucnym. Wyniki badania echokardiograficznego pozwalają na wyodrębnienie grupy chorych, u których należy rozważyć dalszą diagnostykę inwazyjną. Zasadność takiej strategii jest powszechnie akceptowana. 
Tabela 4. Ocena ciśnienia w prawym przedsionku (RA, right atrium) na podstawie szerokości żyły głównej dolnej (ICV, inferior vena cava) i jej podatności oddechowej (na podstawie [5, 6])

$\begin{array}{lcc}\begin{array}{l}\text { Szerokość ICV } \\ {[\mathrm{mm}]}\end{array} & \begin{array}{c}\text { Wdechowe } \\ \text { zapadanie } \\ \text { ICV (\%) }\end{array} & \begin{array}{c}\text { Ciśnienie w RA; } \\ \text { zakres; wartość średnia } \\ {[\mathrm{mm} \mathrm{Hg}]}\end{array} \\ <21 & >50 & \text { Prawidłowe; 0-5; śr. 3 } \\ <21 & <50 & \text { umiarkowanie podwyższone; } \\ >21 & >50 & 5-10 ; \text { śr. 8 } \\ >21 & <50 & \text { wysokie; 10-20; śr. 15 }\end{array}$

Główne parametry hemodynamiczne oceniane podczas badania echokardiograficznego to ciśnienie w RA oraz ciśnienie w RV i w tętnicy płucnej.

Ocena żyły głównej dolnej (IVC, inferior vena cava), według aktualnych zaleceń, powinna być rutynowym elementem badania echokardiograficznego, pozwalającym ocenić ciśnienie panujące w RA [19]. Podtrzymano dotychczasową, uporządkowaną w poprzednich wytycznych, metodyke oszacowanie tego ciśnienia na podstawie pomiaru średnicy IVC i jej zmienności zależnej od fazy oddechu. Autorzy zwracają uwagę, że opisywana metoda jest najdoskonalsza w wypadku ciśnień niskich lub wysokich, a mniej dokładna dla wartości pośrednich. Prawidłowe ciśnienie w RA mieści się w przedziale $0-5 \mathrm{~mm} \mathrm{Hg}$, średnio - $3 \mathrm{~mm} \mathrm{Hg}$, przy czym zaleca się podanie wartości średniej (nie zakresu). U pacjentów z umiarkowanie podwyższonym ciśnieniem w RA, wynoszącym średnio $8 \mathrm{~mm} \mathrm{Hg}$, należy uwzględnić obecność, bądź brak, innych wskaźników podwyższonego ciśnienia (np. powiększenie RA, uwypuklenie przegrody międzyprzedsionkowej w kierunku lewego przedsionka, wsteczny kierunek przepływu krwi w żyłach wątrobowych, wentylacja respiratorem). Ocenę wartości ciśnienia w RA w zależności od średnicy i podatności oddechowej IVC przedstawiono w tabeli 4.

Skurczowe ciśnienie w prawej komorze (RVSP, right ventricular systolic pressure) jest równe skurczowemu ciśnieniu w tętnicy płucnej - po wykluczeniu nielicznych przypadków obecności przeszkody (zwężenia) w odpływie krwi z RV. Powszechnie stosowaną metodą oceny RVSP jest pomiar skurczowego gradientu ciśnienia między RV a RA (TRPG, tricuspidal regurgitation pressure gradient), powiększonego o wartość oszacowanego ciśnienia w RA. Gradient ten oblicza się za pomocą uproszczonego równania Bernoulliego - z maksymalnej prędkości fali zwrotnej trójdzielnej (TR, tricuspidal regurgitation). Metoda ta jest rekomendowana w zaleceniach ASE z 2010 roku [5, 20]. Zalecenia z 2015 roku nie zawierają nowych informacji na temat parametrów hemodynamicznych.

\section{Podsumowanie}

Wykazano, że pacjenci z niewydolnością lewej komory, u których rozwinęły się objawy niewydolności RV, charakteryzują się 2-krotnie większą umieralnością, a obecność nadciśnienia płucnego jest niezależnym czynnikiem ryzyka zgonu pacjentów z niewydolnością serca [14, 15]. Ocena prawych jam serca jest stałym elementem każdego badania echokardiograficznego. Szczególne znaczenie ma u chorych z niewydolnością serca, także u tych bez klinicznych objawów niewydolności prawokomorowej. Badanie musi obejmować pomiar wielkości prawych jam serca, ocenę funkcji skurczowej RV (np. TAPSE) oraz ocenę przepływów metodami doplerowskimi (TRPG lub RVSP). Pacjenci z grupy wyższego ryzyka - z rozpoznaną niewydolnością lewej komory, według doświadczeń autorów, wymagają rozszerzenia badania prawych jam serca. Ocena wielkości jam serca, obok wartości liniowych (wymiarów), powinna zawierać parametry uwzględniające powierzchnię RA (zwłaszcza w przypadku powiększenia jego wymiarów) i ewentualnie RV. Należy także oznaczyć przynajmniej jeden parametr ilościowy funkcji RV, co jest szczególnie przydatne w dalszej obserwacji pacjenta z niewydolnością serca. Codzienna praktyka kliniczna wskazuje, że w tej grupie chorych najczęściej wykonuje się prosty i powtarzalny pomiar TAPSE. Zasadne wydaje się polecanie wykorzystywania w tym celu również pomiaru maksymalnej skurczowej prędkości S' ruchu pierścienia trójdzielnego. Niezbędna jest także, szczególnie w przypadku obecności istotnej fali niedomykalności trójdzielnej, ocena parametrów hemodynamicznych - ciśnienia w RA, skurczowego gradientu ciśnienia między RV a RA, RVSP i skurczowego ciśnienia w tętnicy płucnej. Chorzy z objawami niewydolności RV wymagają możliwie najszerszej oceny opisywanych wyżej parametrów. Szczegółowy dobór metod zastosowanych u poszczególnych pacjentów zawsze jest indywidualny, zależny od sytuacji i problemu klinicznego, dostosowany do warunków i możliwości badania, uwzględniający także umiejętności i doświadczenie wykonującego badanie. Dlatego też w wytycznych zawarto szerokie spektrum metod oceny prawych jam serca, wartościując je i pozycjonując zależnie od udokumentowanej naukowo przydatności. W przypadku ograniczeń w zastosowaniu optymalnej metody oceny danego parametru w zaleceniach oferuje się metody alternatywne. W przypadku parametrów zależnych od wzrostu i masy ciała (bądź płci) zaleca się ich indeksację i zawarcie odpowiedniej interpretacji w raporcie badania. Brak odniesienia uzyskanego wyniku do indywidualnych cech badanego, zwłaszcza przy skrajnych wartościach, może prowadzić do błędnej klasyfikacji poza zakres referencyjny. Wytyczne porządkują metodykę i standaryzują badanie echokardiograficzne, zwiększając jego wartość kliniczną. Ich autorzy zachęcają również do 
stosowania nowszych, obiecujących narzędzi (3D, dopler tkankowy, strain, strain rate) o mniej udokumentowanym znaczeniu, przewidując ich dalszy rozwój.

\section{Konflikt interesów}

Autorzy deklarują brak konfliktu interesów.

\section{Abstract}

Cardiac imaging is crucial in diagnostics and monitoring of cardiovascular diseases. Among all imaging techniques, studies, echocardiography is a method of choice considering its availability, accuracy, safety and cost effectiveness. Significant prognostic value of the right ventricular function makes its evaluation an indispensable part of daily practice. Another updated edition of guidelines on optimal echocardiographic methodology providing new set of reference values confirms the importance of the right heart assessment in clinical setting. These new recommendations on adult echocardiography were endorsed by American Society of Echocardiography and European Association of Cardiovascular Imaging and published in 2015. The document underlines the need for right heart evaluation during each and every echocardiographic examination using all available acoustic windows and combining the findings with clinical data. Detailed choice of methods is individualized with regard to the clinical situation, symptoms, equipment, skills and echocardiographers' experience. The guidelines highlight the need to relate echocardiographic findings to the individual features, especially in case of extreme values (body size), to eliminate potential interpreting mistakes in individuals with extreme weight and height. The guidelines organize the methodology of echocardiographic examination significantly and increase its clinical value.

Key words: echocardiography, right ventricle, right atrium, guidelines

Folia Cardiologica 2017; 12, 2: 171-178

\section{Piśmiennictwo}

1. Ponikowski P, Voors AA, Anker SD, et al. Authors/Task Force Members, Document Reviewers, Authors/Task Force Members. 2016 ESC Guidelines for the diagnosis and treatment of acute and chronic heart failure: The Task Force for the diagnosis and treatment of acute and chronic heart failure of the European Society of Cardiology (ESC)Developed with the special contribution of the Heart Failure Association (HFA) of the ESC. Eur Heart J. 2016; 37(27): 2129-2200, doi: 10.1093/eurheartj/ehw128, indexed in Pubmed: 27206819.

2. Haddad F, Doyle R, Murphy DJ, et al. Right ventricular function in cardiovascular disease, part II: pathophysiology, clinical importance, and management of right ventricular failure. Circulation. 2008; 117(13): 1717-1731, doi: 10.1161/CIRCULATIONAHA.107.653584, indexed in Pubmed: 18378625.

3. Ghio S, Gavazzi A, Campana C, et al. Independent and additive prognostic value of right ventricular systolic function and pulmonary artery pressure in patients with chronic heart failure. J Am Coll Cardiol. 2001; 37(1): 183-188, indexed in Pubmed: 11153735.

4. McMurray JJV, Adamopoulos S, Anker SD, et al. Task Force for the Diagnosis and Treatment of Acute and Chronic Heart Failure 2012 of the European Society of Cardiology, ESC Committee for Practice Guidelines, ESC Committee for Practice Guidelines. ESC Guidelines for the diagnosis and treatment of acute and chronic heart failure 2012: The Task Force for the Diagnosis and Treatment of Acute and Chronic Heart Failure 2012 of the European Society of Cardiology. Developed in collaboration with the Heart Failure Association (HFA) of the ESC. Eur Heart J. 2012; 33(14): 1787-1847, doi: 10.1093/eurheartj/ ehs104, indexed in Pubmed: 22611136.

5. Rudski LG, Lai WW, Afilalo J, et al. Guidelines for the echocardiographic assessment of the right heart in adults: a report from the American
Society of Echocardiography endorsed by the European Association of Echocardiography, a registered branch of the European Society of Cardiology, and the Canadian Society of Echocardiography. J Am Soc Echocardiogr. 2010; 23(7): 685-713; quiz 786, doi: 10.1016/j. echo.2010.05.010, indexed in Pubmed: 20620859.

6. Lang RM, Badano LP, Mor-Avi V, et al. Recommendations for cardiac chamber quantification by echocardiography in adults: an update from the American Society of Echocardiography and the European Association of Cardiovascular Imaging. J Am Soc Echocardiogr. 2015; 28(1): 1-39.e14, doi: 10.1016/j.echo.2014.10.003, indexed in Pubmed: 25559473.

7. Lang RM, Badano LP, Tsang W, et al. American Society of Echocardiography, European Association of Echocardiography, American Society of Echocardiography, European Association of Echocardiography. EAE/ASE recommendations for image acquisition and display using three-dimensional echocardiography. J Am Soc Echocardiogr. 2012; 25(1): 3-46, doi: 10.1016/j.echo.2011.11.010, indexed in Pubmed: 22183020.

8. Shimada YJ, Shiota M, Siegel RJ, et al. Accuracy of right ventricular volumes and function determined by three-dimensional echocardiography in comparison with magnetic resonance imaging: a meta-analysis study. J Am Soc Echocardiogr. 2010; 23(9): 943-953, doi: 10.1016/j. echo.2010.06.029, indexed in Pubmed: 20797527.

9. Gaynor SL, Maniar HS, Prasad SM, et al. Reservoir and conduit function of right atrium: impact on right ventricular filling and cardiac output. Am J Physiol Heart Circ Physiol. 2005; 288(5): H2140-H2145, doi: 10.1152/ajpheart.00566.2004, indexed in Pubmed: 15591102.

10. Kou S, Caballero L, Dulgheru R, et al. Echocardiographic reference ranges for normal cardiac chamber size: results from the NORRE 
study. Eur Heart J Cardiovasc Imaging. 2014; 15(6): 680-690, doi: 10.1093/ehjci/jet284, indexed in Pubmed: 24451180.

11. Quraini D, Pandian NG, Patel AR. Three-dimensional echocardiographic analysis of right atrial volume in normal and abnormal hearts: comparison of biplane and multiplane methods. Echocardiography. 2012; 29(5): 608-613, doi: 10.1111/j.1540-8175.2011.01640.x, indexed in Pubmed: 22329495.

12. Mor-Avi V, Lang RM, Badano LP, et al. Current and evolving echocardiographic techniques for the quantitative evaluation of cardiac mechanics: ASE/EAE consensus statement on methodology and indications endorsed by the Japanese Society of Echocardiography. J Am Soc Echocardiogr. 2011; 24(3): 277-313, doi: 10.1016/j. echo.2011.01.015, indexed in Pubmed: 21338865.

13. Bhave NM, Lang RM. Evaluation of left ventricular structure and function by three-dimensional echocardiography. Curr Opin Crit Care. 2013; 19(5): 387-396, doi: 10.1097/MCC.0b013e328364d75e, indexed in Pubmed: 23995127.

14. Sugeng L, Mor-Avi V, Weinert L, et al. Multimodality comparison of quantitative volumetric analysis of the right ventricle. JACC Cardiovasc Imaging. 2010; 3(1): 10-18, doi: 10.1016/j.jcmg.2009.09.017, indexed in Pubmed: 20129525.

15. Innelli P, Esposito R, Olibet M, et al. The impact of ageing on right ventricular longitudinal function in healthy subjects: a pulsed tissue Doppler study. Eur J Echocardiogr. 2009; 10(4): 491-498, doi: 10.1093/ ejechocard/jen313, indexed in Pubmed: 19073708.
16. Spruijt OA, Di Pasqua MC, Bogaard HJ, et al. Serial assessment of right ventricular systolic function in patients with precapillary pulmonary hypertension using simple echocardiographic parameters: A comparison with cardiac magnetic resonance imaging. J Cardiol. 2017; 69(1): 182-188, doi: 10.1016/j.jjcc.2016.02.019, indexed in Pubmed: 27012754.

17. Frea S, Pidello S, Bovolo V, et al. Prognostic incremental role of right ventricular function in acute decompensation of advanced chronic heart failure. Eur J Heart Fail. 2016; 18(5): 564-572, doi: 10.1002/ ejhf.504, indexed in Pubmed: 26991036.

18. Garcia Gigorro R, Renes Carreño E, Mayordomo S, et al. Evaluation of right ventricular function after cardiac surgery: the importance of tricuspid annular plane systolic excursion and right ventricular ejection fraction. J Thorac Cardiovasc Surg. 2016; 152(2): 613-620, doi: 10.1016/j.jtcvs.2016.04.041, indexed in Pubmed: 27174515.

19. Brennan JM, Blair JE, Goonewardena S, et al. Reappraisal of the use of inferior vena cava for estimating right atrial pressure. J Am Soc Echocardiogr. 2007; 20(7): 857-861, doi: 10.1016/j.echo.2007.01.005, indexed in Pubmed: 17617312.

20. Özpelit E, Akdeniz B, Özpelit EM, et al. Impact of Severe Tricuspid Regurgitation on Accuracy of Echocardiographic Pulmonary Artery Systolic Pressure Estimation. Echocardiography. 2015; 32(10): 1483-1490, doi: 10.1111/echo.12912, indexed in Pubmed: 25735427. 